\title{
Carta-resposta a Cartas a Cristina: aos educadores, aproximações e desafios na obra de Paulo Freire
}

\author{
Jhonathas Armond Assis Ramos' (D)
}

FREIRE, Paulo. Cartas a Cristina: reflexões sobre minha vida e minha práxis. 2. ed. São Paulo: Paz e Terra, 2015.

Paulo Freire educador; Paulo Freire ser humano. Assim se poderia definir a obra Cartas a Cristina. Esse livro-carta, pela simplicidade com que o autor escreve em sua primeira parte e pela complexidade com que se depara na segunda, é, ao mesmo tempo, uma aproximação que o leitor faz de Freire menino e de Freire intelectual. $\mathrm{O}$ tom narrativo, muito notável desde as primeiras páginas, possibilita a toda pessoa que leia tal obra reconhecer-se e se aproximar da própria infância por meio das palavras de Paulo Freire. Já a nuance mais teórica é capaz de revelar aquilo pelo que seu autor se tornou conhecido, sem que, no entanto, sua leitura impeça de espelhar-se sempre naquele mesmo menino.

Incrível, portanto, é pensar a relação entre estes dois Paulos: o menino e o intelectual. Uma coisa seria o menino contando de suas experiências recentes; outra, o menino se imaginando quem se tornaria no futuro. Outra coisa, ainda, é ver o renomado educador, passadas tantas vivências, projetar seu olhar para quem era anos atrás e esmiuçar suas lembranças, aproximando essas duas figuras que é ele. Freire faz isso de tal maneira, que o leitor é capaz de se deparar com suas próprias lembranças, analisando cada uma, de modo a buscar na própria memória o que o fizera chegar até onde está atualmente. É possivel, nesse sentido, pensar que Paulo Freire apenas se tornou quem se tornou porque viveu episódios como os que ele mesmo conta em Cartas a Cristina, e que esses mesmos episódios somente foram lembrados e se fizeram presentes no livro porque Freire lhes atribuía significados fundamentais para ter se tornado o educador que posteriormente $o$ mundo todo viria a conhecer.

$\mathrm{Na}$ terceira carta, por exemplo, intitulada "As almas penadas falando manhosamente e o relógio grande da sala na qual nasci", o autor comenta sobre o medo que tinha das "almas do outro mundo" ao dormir e sobre como foi se educando para criar coragem:

Aguçando a percepção nos momentos em que brincava é que comecei a captar, às vezes deslumbrado, na totalidade sonora dos dias, um sem-número de ruídos antes imperceptíveis. Este exercício me fortalecia para enfrentar à noite as apreensões que

'Universidade Federal de São João del-Rei, São João del-Rei, MG, Brasil. 
me consumiam. Em última análise, o desafio de meu medo e a decisão de não me submeter docilmente a ele me levaram, em tenra idade, a transformar a minha cama, no silêncio do meu quarto, numa espécie sui generis de contexto teórico. A partir dele dava começo às minhas primeiras "reflexões críticas" sobre o meu contexto concreto que, àquela época, se reduzia ao quintal de minha casa e aos trezentos metros que a separavam da escolinha primária em que me iniciava. (Freire, 2015, p. 61)

Nesse trecho, pode-se perceber como o olhar do presente para sua remota infância, especificamente nesse caso, para o episódio do medo de assombrações, possibilitou a Freire afirmar que uma postura sua no passado se construíra de tal forma, que ele, agora já o educador que se tornara, pudesse analisar aquele acontecimento como formador de quem ele viria a ser. O exercício de buscar razões de seu medo, para ele, havia sido o início da formação crítica que ele mesmo, depois, podia afirmar que foi estabelecendo em sua relação com o mundo.

Interessante também quando Paulo Freire fala de sua alegria em ir para a escola, quando tinha aulas com a professora Eunice. Dizia ele: "Não havia,em última análise, entre a orientação de meus pais em casa e a de Eunice, na sua escolinha particular, nenhuma ruptura. Em casa como na escolinha, eu era convidado a conhecer e não reduzido a um 'depósito vazio' que devesse ser enchido de conhecimento" (Freire, 2015, p. 63).

A oportunidade de ter a criatividade e a curiosidade estimuladas pela professora, de modo harmonioso com a educação em casa, àquela época, fez-lhe, mais tarde, não somente poder analisar aquele período como formador de sua criticidade, mas, pode-se dizer, foi essencial e, diga-se, coerente, com uma das lutas mais empenhadas de Freire como educador. Aquilo o despertava para sua formação crítica e se mostrava, assim, após muito estudo, como a exemplificação vivida por ele próprio de uma experiência em que a escola era um ambiente de conhecimento autêntico e democrático, e não de repetição e alienação.

Já trabalhando como diretor no Sesi, pode-se ver Paulo Freire atuando politicamente em busca de uma escola mais democrática, envolvendo em suas práticas professores, pais, funcionários e a comunidade à sua volta. Seu modo crítico e político de trabalhar foi transformando aos poucos aquele ambiente, levando todos ali a questionarem mais suas atitudes e a atuarem mais tal como ele os incentivava, deixando de ser objetos, tornando-se mais sujeitos de suas histórias.

Destacam-se, ainda, dois episódios também marcantes nesse momento inicial do livro. O primeiro é aquele em que Freire conta quando os pais que queriam que seus filhos aprendessem com a Carta do $\mathrm{ABC}$ passam a ver mais claramente que não tinham bons argumentos para tal reivindicação. $\mathrm{O}$ segundo diz respeito à fala do zelador Francisco em uma das reuniões à frente do Departamento Regional do Sesi propostas pelo educador, ocasião em que Paulo Freire traz uma reflexão sobre a coerência entre o que se diz acreditar e aquilo que se faz aproximar ou não desses discursos:

Questões de classe social, ontem, como hoje. Em certos programas de televisão em que, em algum momento, o garçom serve um cafezinho ao entrevistado e ao entrevistador, jamais vi ou ouvi um deles, olhando cortesmente ao garçom, dizer-lhe: "Muito obrigado.” Às vezes, entrevistados progressistas. É como se o garçom não fosse gente, fosse um robô programado para servir. 
O elitismo que nos empapa não nos permite perceber a incoerência entre nossos discursos libertários e o indiferentismo diante de uma pessoa reduzida à condição de quase coisa. E não se diga que isso é um problema menor. (Freire, 2015, p. 157)

Mais do que transformações no campo pedagógico, percebe-se, aqui, Paulo Freire humanamente provocando alterações no campo social e da vida particular das pessoas com quem convivia. Perfeito exemplo daquilo que ele acreditava ser essencial na vida de todo educador progressista: a coerência entre o que se diz ideal e o que se faz para chegar a essa mesma concepção de mundo ideal.

A partir da segunda parte de Cartas a Cristina, o leitor se depara, já, com Freire discursando sobre temas por ele considerados importantes na busca por uma sociedade mais democrática. $\mathrm{Na} 14^{\text {a }}$ carta ("Educação e democracia"), por exemplo, o autor, ao falar da necessidade do ensino da democracia em nossa sociedade, afirma que a escola precisa ser um ensaio do que almejamos, mais uma vez mostrando que essa luta não faz sentido se ocorre em "salas resguardadas do mundo, com educadores e educadoras que apenas depositam conteúdos nas cabeças vazias de submissos educandos"(Freire, 2015, p.245, grifos do original). Como é possível observar, essa coerência fortemente defendida por Paulo Freire, tão bem tocada no texto, pode ser considerada um dos pontos mais admiráveis da referida obra, assim como de outras do autor, o que é reflexo, mesmo, de sua própria práxis durante a vida como educador.

Cartas a Cristina fala de educação, democracia,liberdade. O livro, de forma humana, mostra um autor estudioso, educador conciso do que afirma e pelo que luta; de forma teórica, revela um ser humano utópico que almeja uma educação que liberte os sujeitos, para que construam uma sociedade regida por uma democracia autêntica. A todas as educadoras e a todos os educadores o livro tem o potencial de provocar uma aproximação única com as ideias de Paulo Freire, sendo uma leitura que impõe desafios para toda uma vida que se faça dedicada à educação.

\section{REFERÊNCIA}

FREIRE, Paulo. Cartas a Cristina: reflexões sobre minha vida e minha práxis. 2. ed. São Paulo: Paz e Terra, 2015.

\section{SOBRE O AUTOR}

Jhonathas Armond Assis Ramos é mestre em processos socioeducativos e práticas escolares pela Universidade Federal de São João Del-Rei (UFSJ). E-mail: jhonathas.armond@gmail.com 